\title{
PENGARUH SISTEM INFORMASI PEROLEHAN DAN PENYUSUTAN AKTIVA TETAP BERBASIS WEB DI PT. HASIL DAMAI TEXTILE BANDUNG
}

\author{
Cahyadi Agustin \\ Program Studi Manajemen Informatika, Politeknik Piksi Ganesha, Bandung, Indonesia \\ Email: cahyadi.agustin3@gmail.com
}

\begin{abstract}
This study aims to create a design of information systems the acquisition and depreciation of web-based fixed assets using php mysql database at PT. Hasil Damai Textile Bandung. Software development method using waterfall. From the research conducted, it was found the problem that the process of recording and calculating depreciation of fixed assets still uses Microsoft excel so it requires a relatively long time and the calculation results are less accurate, and data storage is less secure and irregular so it is difficult to identify fixed assets that will expire depreciation.
\end{abstract}

Keywords: System information, Depreciation of fixed assets, Waterfals and MySql

\section{PENDAhuluan}

\subsection{Latar belakang}

Perkembangan teknologi sangat pesat di Indonesia maupun di negara-negara diseluruh dunia, menjadi sebuah tantangan dan motivasi setiap kalangan baik individu, perusahaan, atau instansi-instansi pemerintah untuk mengikuti kemajuan teknologi. Dengan adanya teknologi yang semakin canggih dan modern maka dapat meringankan pekerjaan yang dilakukan semua orang. Selain itu teknologi juga dapat dimodifikasi sesuai keinginan atau kebutuhannya. Teknologi dalam bentuk informasi komunikasi maupun teknologi lainnya menjadi unsur yang menjembatani data dan informasi dalam segala aspek kehidupan. Untuk mendapatkan suatu informasi diperlukan suatu sistem. Peranan sistem informasi terhadap kemajuan perusahaan sudah tidak diragukan lagi dengan dukungan sistem informasi yang baik maka sebuah perusahaan akan memiliki berbagai keunggulan kompetitif sehingga mampu bersaing dengan perusahaan lain. Dalam menghadapi persaingan tersebut selain didukung oleh sistem informasi yang baik perusahaan harus mempertahankan kelangsungan hidupnya melalui pencapaian tujuan, suatu tujuan akan tercapai apabila perusahaan dikelola dengan baik, sehingga sesuai dengan harapan yang telah ditetapkan oleh perusahaan. Tujuan suatu perusahaan adalah memperoleh laba yang optimal atas investasi yang telah ditanamkan dalam perusahaan, salah satu bentuk investasi tersebut adalah aktiva tetap.

Aktiva tetap merupakan salah satu kelompok harta yang digunakan oleh perusahaan untuk mendukung kegiatan operasional perusahaan dalam melakukan aktivitasnya. Sebagai contoh, gedung sebagai tempat untuk bekerja, peralatan operasional, mesin-mesin produksi atau kendaraan yang digunakan untuk kegiatan operasional oleh perusahaan. Aktiva tetap adalah harta berwujud yang diperoleh dalam bentuk siap pakai atau dengan dibangun lebih dahulu, yang digunakan dalam operasi perusahaan, tidak dimaksudkan untuk dijual dalam rangka kegiatan normal perusahaan dan mempunyai masa manfaat lebih dari satu tahun. Dalam sistem manajemen akuntansi, aktiva tetap wajib mengalami depresiasi atau lebih dikenal dengan istilah "penyusutan".

Penyusutan aktiva tetap merupakan alokasi biaya dari harga perolehannya, proses penyusutan aktiva tetap tidak boleh sembarangan karena nilai penyusutan yang diberikan pada sebuah aktiva tetap berbedabeda sesuai dengan fungsi dan kondisi aktiva tetap yang ada. PT. Hasil Damai Textile adalah perusahaan manufaktur yang berlokasi di Jalan Cisirung Km. 2 Cangkuang Barat Dayeuh Kolot Bandung. Kegiatan utamanya adalah memproduksi Polyester Spunbond dan mendaur ulang PET bottles menjadi polyster Staple Fiber, dalam hal tersebut dibutuhkan mesin-mesin produksi, dan peralatan operasional lainnya untuk menunjang seluruh kegiatan produksi.

Sistem Informasi yang sedang berjalan di PT. Hasil Damai Textile masih banyak kekurangan hal ini terbukti dari adanya kendala saat mengolah data penyusutan aktiva tetap. Perusahaan mengahadapi permasalahan dalam proses penyusutan aktiva tetap yang mana sebagian prosesnya masih manual sehingga rentan terjadi kesalahan dalam pengolahan data dan perhitungan penyusutan aktiva tetap. Selain itu perusahaan sulit mengidentifikasi aktiva tetap yang akan habis masa penyusutannya serta saat pembuatan rekap laporan aktiva selama setahun perusahaan harus melakukan penggabungan beberapa file menjadi satu sehingga tidak mudah bagi perusahaan untuk mengambil keputusan dalam menentukan 
pembelian aktiva tetap yang baru. Namun dengan adanya sistem informasi masalah tersebut diharapkan dapat teratasi dan kinerja perusahaan menjadi semakin baik. Perusahaan tidak akan mengalami kesulitan dalam melakukan proses penyusutan aktiva tetap dan pembuatan rekap laporan aktiva tetap selama setahun.

\subsection{Tujuan Penelitian}

Mengetahui sistem informasi perolehan dan penyusutan aktiva tetap yang sedang berjalan di PT. Hasil Damai Textile dan untuk mengetahui kendala yang dihadapi dalam sistem informasi perolehan dan penyusutan aktiva tetap kemudian supaya yang dilakukan untuk mengatasi kendala dalam sistem informasi perolehan dan penyusutan aktiva tetap dan Untuk merancang sistem informasi perolehan dan penyusutan aktiva tetap menggunakan PHP dan MYSQL di PT. Hasil Damai Textile.

\section{MATERI DAN METODE}

\subsection{Teori-Teori Tentang Konsep Sistem}

a. Pengertian Perancangan

Menurut Mohamad Subhan (2012:109), dalam bukunya yang berjudul Analisa Perancangan Sistem mengungkapkan: "perancangan adalah proses pengembangan spesifikasi baru berdasarkan rekomendasi hasil analisis sistem".

\section{b. Konsep Dasar Sistem}

Secara umum, sistem merupakan satu kesatuan yang terdiri dari komponen atau elemen yang berbedabeda tetapi saling terhubung antara elemen yang satu dengan yang lainnya untuk mencapai suatu tujuan bersama. Unsur-unsur yang terdapat dalam sistem yaitu:

1) Adanya sekumpulan objek (objectives) (unsur-unsur atau bagian-bagian atau elemen-elemen).

2) Adanya interaksi atau hubungan (interrealatedness) antara unsur-unsur (bagian-bagian, elemenelemen).

3) Adanya sesuatu yang mengikat unsur-unsur (working independently and jointly) (bagian-bagian, elemen-elemen saling tergantung dan bekerja sama) tersebut menjadi suatu kesatuan (unity).

4) Berada dalam suatu lingkungan (environment) yang kompleks (complex).

5) Terdapat tujuan bersama (output), sebagai hasil akhir. Karakteristik Sistem dibagi menjadi beberapa macam yang disajikan pada Gambar 1 .

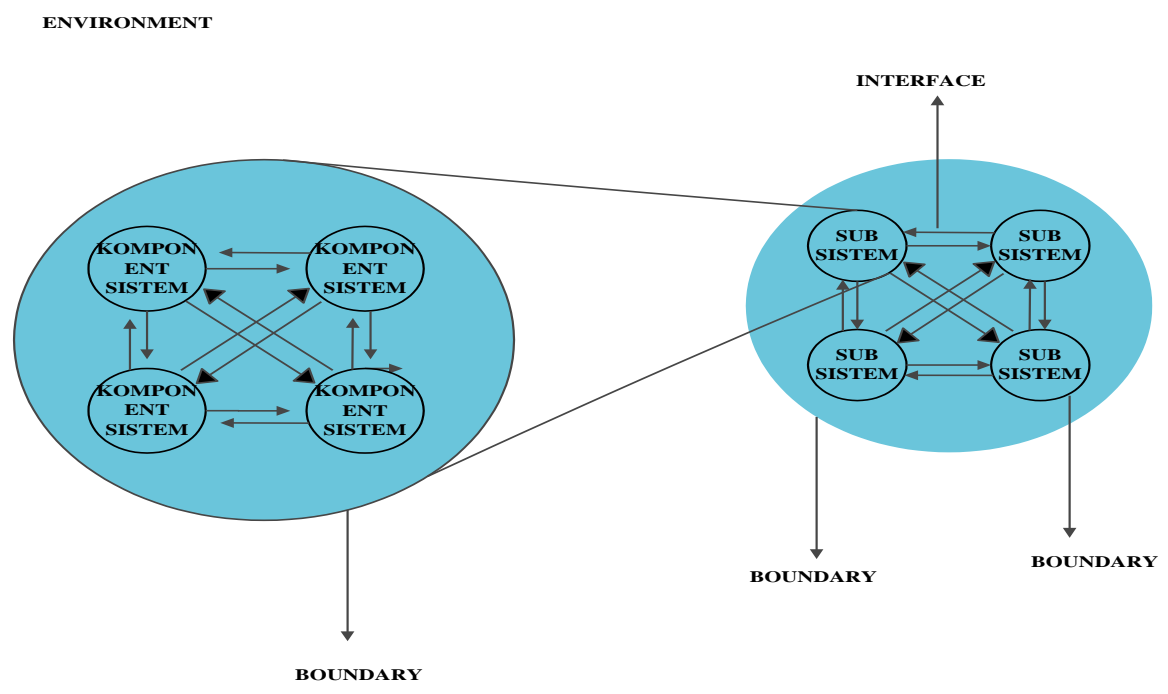

Keterangan:

Gambar 1. Karakteristik Managemen Sistem

1) Komponen Sistem (components)

2) Ruang Lingkup Sistem (Boundary)

3) Lingkungan Luar Sistem (Environtment)

4) Penghubung Sistem (Interface)

5) Masukan Sistem (Input) 
6) Keluaran Sistem (Output)

7) Pengolahan Sistem ( Process)

8) Sasaran Sistem (Objective)

Siklus hidup sistem adalah proses evalusioner yang diikuti dalam penerapan sistem atau subsistem informasi berbasis komputer. Siklus hidup sistem terdiri dari rangkaian tugas yang mengikuti langkahlangkah pendekatan sistem, karena tugas-tugas tersebut mengikuti pola yang teratur dan dilakukan secara top down. Siklus hidup sistem sering disebut sebagai pendekatan air terjun (waterfall approach) bagi pembangunan dan pengembangan sistem.

\section{c. Konsep Dasar Informasi}

Pengertian informasi secara umum yaitu informasi dapat didefinisikan sebagai hasil dari pengolahan data dalam suatu bentuk yang lebih berguna dan lebih berarti bagi penerimanya yang menggambarkan suatu kejadian-kejadian yang nyata yang digunakan untuk pengambilan keputusan.

Fungsi utama informasi adalah menambah pengetahuan atau mengurangi ketidakpastian pemakaian informasi. Informasi yang disampaikan kepada pemakai mungkin merupakan hasil dari data yang dimasukkan dalam pengolahan. Akan tetapi dalam pengambilan keputusan yang kompleks, informasi hanya dapat menambah kemungkinan kepastian atau mengurangi bermacam-macam pilihan. Informasi yang disediakan bagi pengambil keputusan memberikan kemungkinan suatu faktor resiko pada tingkattingkat pendapatan yang berbeda.

\section{d. Konsep Dasar Sistem Informasi}

Sistem informasi merupakan suatu sistem di dalam suatu organisasi yang mempertemukan kebutuhan pengolahan transaksi harian yang mendukung fungsi organisasi yang bersifat manajerial dalam kegiatan strategi dari suatu organisasi untuk dapat menyediakan kepada pihak luar tertentu dengan laporan laporan yang diperlukan. Sistem informasi memiliki komponen-komponen sistem yang terdiri dari:

1) Blok Masukan (input block)

2) Blok Model (model block)

3) Blok Keluaran (output block)

4) Blok Teknologi (technology block)

5) Blok Basis Data (database block)

6) Blok Kendali (control block)

Sistem akuntansi adalah organisasi formulir, catatan-catatan dan laporan-laporan yang dikoordinasikan sedemikian rupa untuk menyediakan informasi keuangan yang dibutuhkan oleh manajemen guna memudahkan pengelolaan perusahaan.

Sistem Informasi Akuntansi adalah susunan berbagai formulir, catatan-catatan peralatan, termasuk komputer dan perlengkapannya serta alat komunikasi tenaga pelaksanaannya, dan laporan yang terkoordinasikan secara erat yang didesain untuk mentrasformasikan data keuangan menjadi informasi yang dibutuhkan manajemen. Perbedaan sistem akuntansi dan sistem informasi akuntansi, jika sistem akuntansi hanya menggunakan formulir, catatan dan laporn sedangkan sistem informasi akuntansi menggunakan formulir, catatan, laporan ditambah dengan perangkat komputer dan jaringan komunikasi.

\subsection{Teori-Teori Pendukung Perusahaan}

\section{a. Aktiva Tetap}

Aktiva tetap adalah aset berwujud yang dimiliki perusahaan yang digunakan untuk aktivitas/operasi perusahaan dan memiliki manfaat lebih dari datu tahun. Aktiva tetap mempunyai sifat tetap atau permanen dibeli untuk digunakan dalam kegiatan normal perusahaan, tidak untuk dijual kembali dan nilainya cukup besar atau material. Karakteristik aktiva tetap yaitu:

1) Aset tersebut digunakan dalam operasi. Hanya aset yang digunakan dalam operasi normal perusahaan saja yang dapat diklasifikasikan sebagai aset tetap (misalnya kendaraan bermotor yang dimiliki oleh dealer mobil untuk dijual kembali harus diperhitungkan sebagai persediaan).

2) Aset tersebut memiliki masa (umur) manfaat yang panjang, lebih dari satu tahun periode.

3) Aset tersebut memiliki substansi fisik. Aset tetap memiliki ciri substansi fisik kasat mata sehingga dibedakan dari aset tak berwujud seperti hak paten dan merek dagang.

Pengadaan aktiva tetap harus benar-benar sesuai dengan kebutuhan sehingga investasi yang dilakukan terhadap aktiva tetap tidak akan sia-sia. Dalam melaksanakan kegiatan atau aktivitas operasionalnya perusahaan selalu menggunakan sarana-sarana penunjang bagi terlaksananya operasi perusahaan untuk mencapai tujuan yang telah ditetapkan yaitu mengoptimalkan laba yang akan dihasilkan. Aktiva tetap beradasarkan jenisnya dibagi sebagai berikut : 
1) Lahan

2) Bangunan/Gedung

3) Mesin

4) Kendaraan

5) Inventaris/Peralatan

6) Prasarana

Aktiva tetap disajikan di neraca di sebelah debet secara sistematis sesuai dengan sifat permanennya (urutan kekekalannya) yaitu dimulai dari aktiva yang paling singkat umurnya atau masa manfaatnya sampai pada aktiva tetap yang paling lama umurnya.

Aktiva tetap harus dicatat sebesar harga perolehan. Harga perolehan meliputi semua pengeluaran yang diperlukan untuk mendapatkan aktiva dan pengeluaran-pengeluaran lain agar aktiva tetap siap untuk digunakan. Pajak penjualan, biaya transportasi, asuransi aktiva tetap selama aktiva dalam perjalanan, pondasi khusus.

\section{b. Penyusutan Aktiva Tetap}

Menurut Waluyo (2010:102), menyatakan bahwa yang dimaksudkan penyusutan adalah alokasi jumlah suatu aset yang dapat disusutkan sepanjang masa manfaat yang diestimasi. Penyusustan atau jumlah disusutkan (depreciable amount) adalah biaya perolehan suatu aset atau jumlah lain yang disubtitusikan untuk biaya dalam laporan keuangan dikurangi nilai sisa. Di Indonesia dasar Penyusutan antara akuntansi dan pajak pada prinsipnya sama. Hal ini dapat dilihat dari pernyataan dasar penyusutan yang terdapat baik pada Standar Akuntansi Keuangan maupun Undang-Undang Pajak Penghasilan. Penyusutan aktiva tetap dapat dilakukan dengan berbagai macam metode antara lain adalah:

1) Berdasarkan waktu

Metode garis lurus, metode ini mengasumsikan bahwa kegunaan aktiva pada setiap periode fiskal selalu sama. Metode ini merupakan metode yang sederhana dan mengabaikan produktivitas dan efisien, digunakan secara luas dan mudah dipahami.

Metode pembebanan menurun, metode ini mempertimbangkan bahwa dengan bertambahnya usia aktiva tetap, maka prestasi yang dihasilkan juga menurun. Metode ini dibagi atas 3 bagian yaitu:

a) Metode jumlah angka tahun

b) Metode saldo menurun/saldo menurun berganda

2) Berdasarkan penggunanya

Metode jam jasa, Metode jumlah unit produksi, Metode berdasarkan kelompok, Metode berdasarkan jenis, Metode Anuitas, dan Sistem persediaan.

\section{c. Teori-Teori Pendukung Komputer}

1) PHP (Hypertext Preprocessor)

Menurut Sutarman (2007:94), menyatakan bahwa : "PHP adalah salah satu bahasa server-side yang disesain khusus untuk aplikasi web, $P H P$ termasuk dalam open source product jadi anda dapat merubah source code dan mendistribusikannya secara bebas". Adapun kelebihan kelebihan PHP yaitu, mudah dibuat dan kecepatan akses tinggi, dapat berjalan dalam web server yang berbeda dan dalam sistem operasi yang berbeda, PHP dapat berjalan dalam sistem operasi UNIX, LINUX, windows dan macintosh, diterbitkan secara gratis, dapat berjalan pada web server microsoft, apache, IIS, xitami, dan sebagainya, termasuk dalam bahasa pemrograman yang embeeded (bisa ditempel atau diletakan dalam tag HTML), serta termasuk server-side programming. PHP (Hypertext Preprocessor) disajikan pada Gambar 2. 


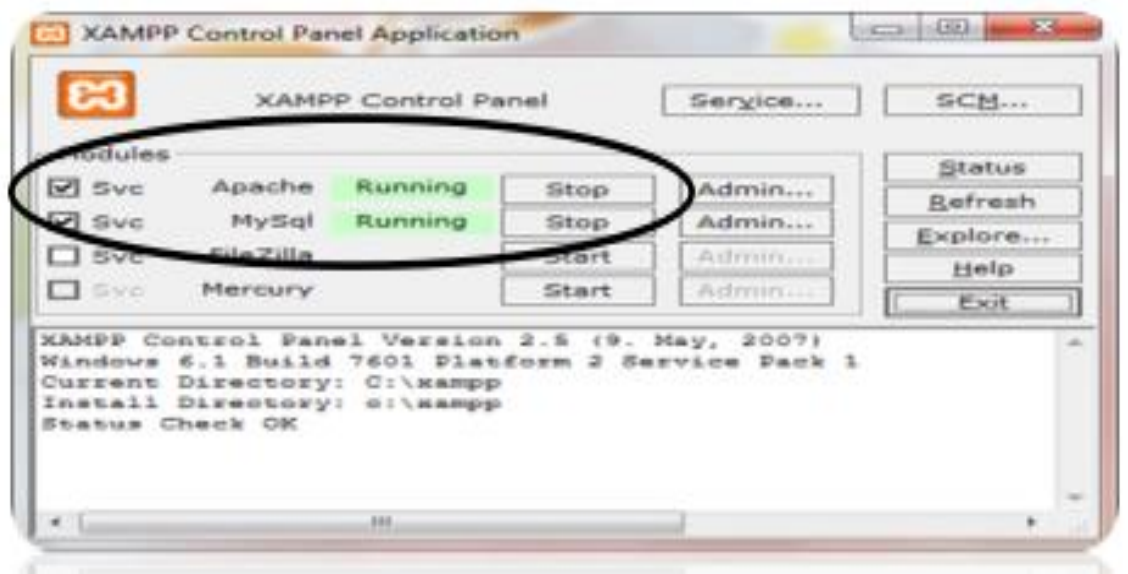

Gambar 2. PHPMyAdmin

2) Mysql

Menurut Sutarman (2007:170), menyatakan bahwa :"Mysql termasuk jenis RDBMS (Relational Database Management System), sehingga istilah seperti tabel, baris, dan kolom tetap digunakan dalam Mysql. Pada Mysql sebuah database mengandung satau atau beberapa tabel, tabel terdiri dari sejumlah baris atau kolom". . EMS SQL Manager For MySQL disajikan pada Gambar 3.

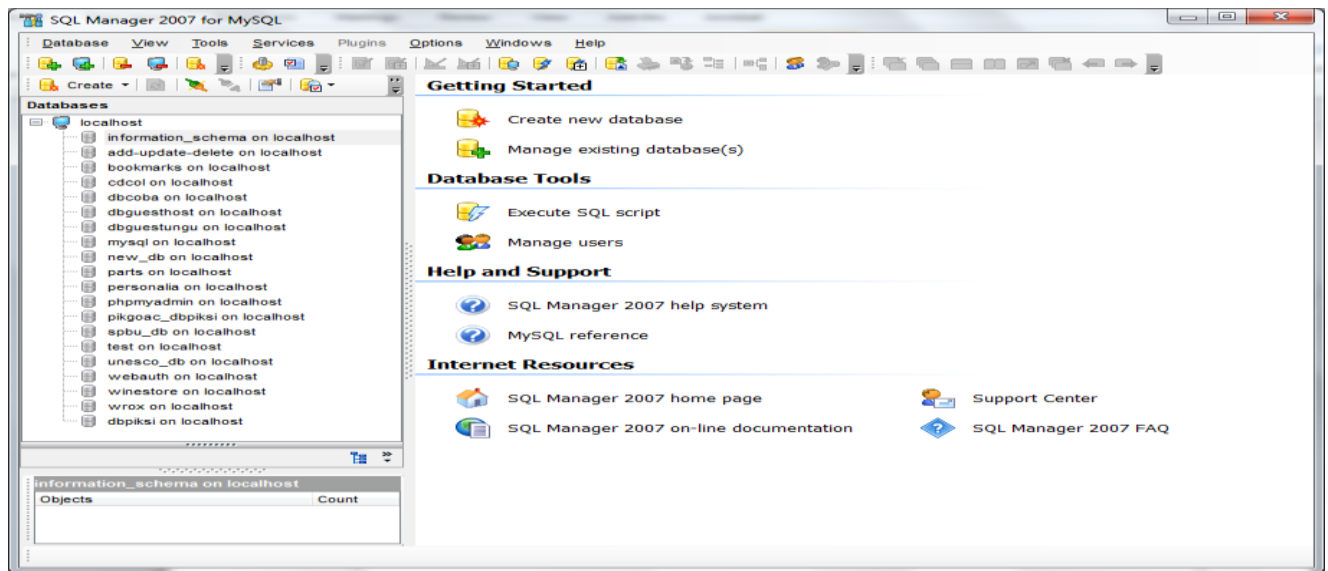

Gambar 3. EMS SQL Manager For MySQL

3) Wamp Server

Wamp Server adalah paket web server yang bekerja secara pada localhost yang dibuat secara independen dan di install pada sistem operasi Windows. Wamp adalah singkatan dari Windows and the principal components of the package: Apache, Mysql and PHP (or Perl or Python). XAMPP control panel disajikan pada Gambar 4.

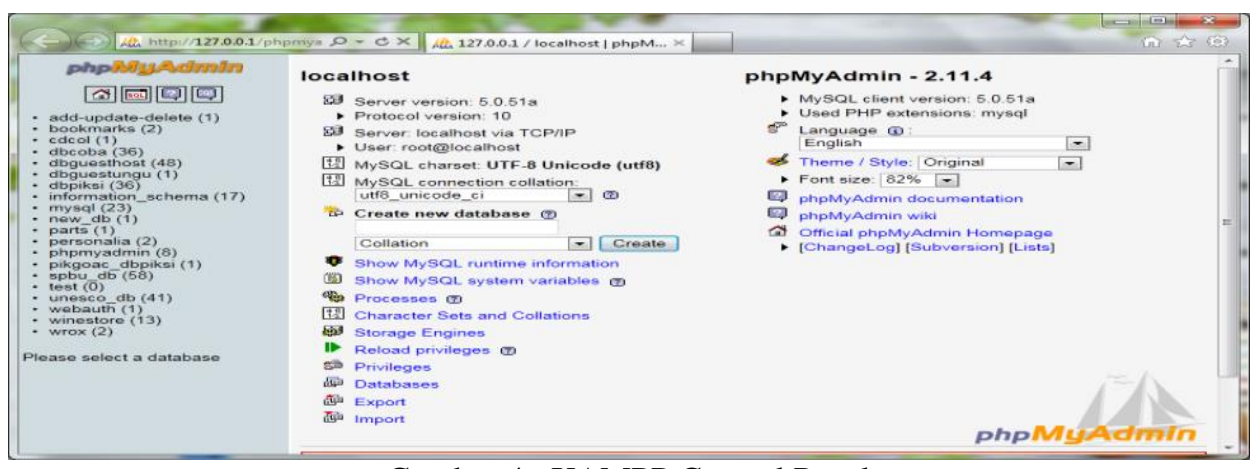

Gambar 4. XAMPP Control Panel 
4) Alur Kerja

Alur kerja ini diturunkan dalam bentuk model sequence diagram untuk menggambarkan modul aplikasi program yang akan dibuat. Alur kerja disajikan pada classdiagram pada Gambar 5.

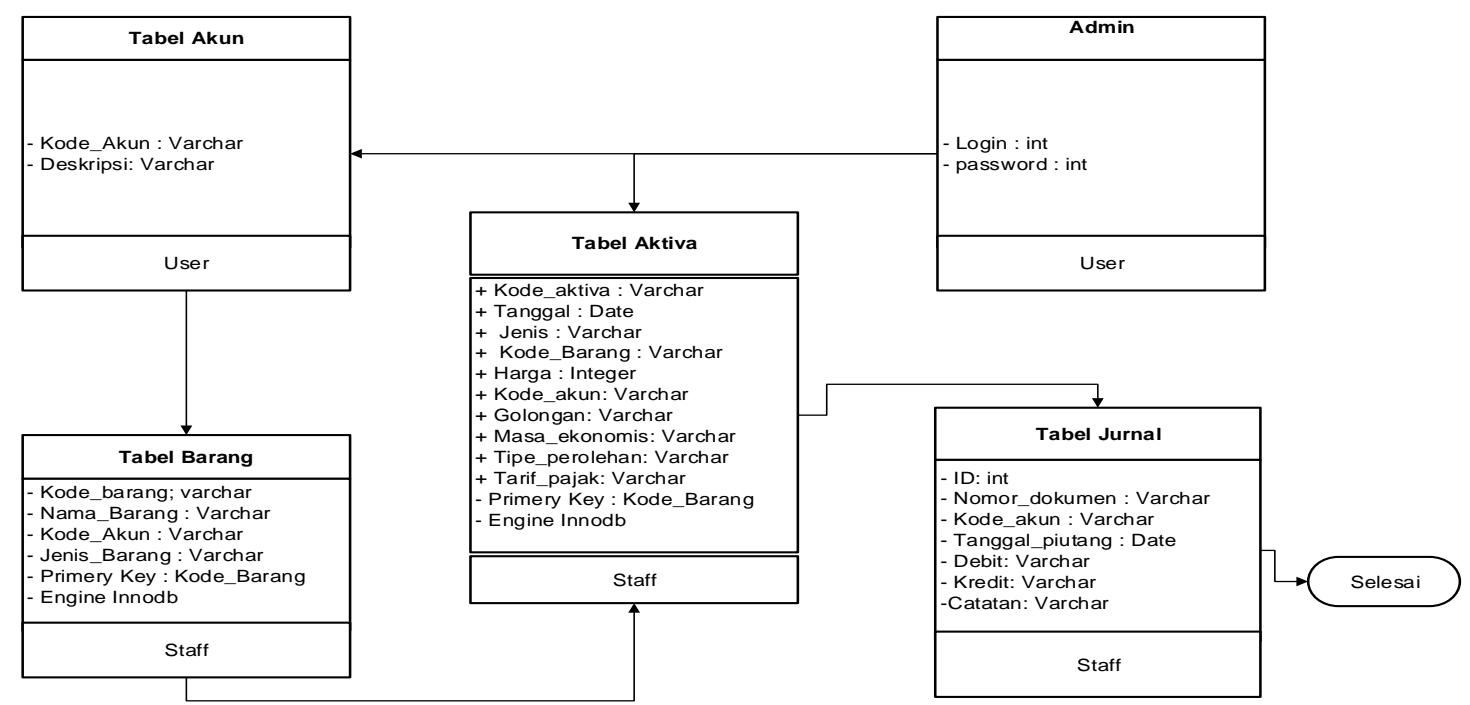

Gambar 5. Class Diagram

\section{d. Spesifikasi Hardware dan Software}

Spesifikasi hardware dan software ini dirancang demi mendukung kelancaran sistem informasi yang digunakan dengan spesifikasi usulan sistem perangkat keras dan perangkat lunaknya adalah :

1) Spesifikasi perangkat keras yang diusulkan adalah :
a) Processor
: Core Celeron
b) Hardisk
: $500 \mathrm{~GB}$
c) Memory
$: 2 \mathrm{~GB}$
d) Monitor
$: 14$ Inci

2) Spesifikasi perangkat lunak yang diusulkan adalah :
a) Sistem Operasi
: Windows 10
b) Bahasa Pemrograman : $p h p$
c) Pengolah Database : :Mysql
d) Perancangan Interface : Microsoft Visio 2013

\subsection{Metode Penelitian}

\section{a. Analisa Pengembangan Sistem}

Penulis menggunakan model air terjun (waterfall) dalam tahap pengembangan sistemdikarenakan pengaplikasiannya mudah dan sistematik. Adapun model waterfall yang digunakan disajikan pada Gambar 6. 


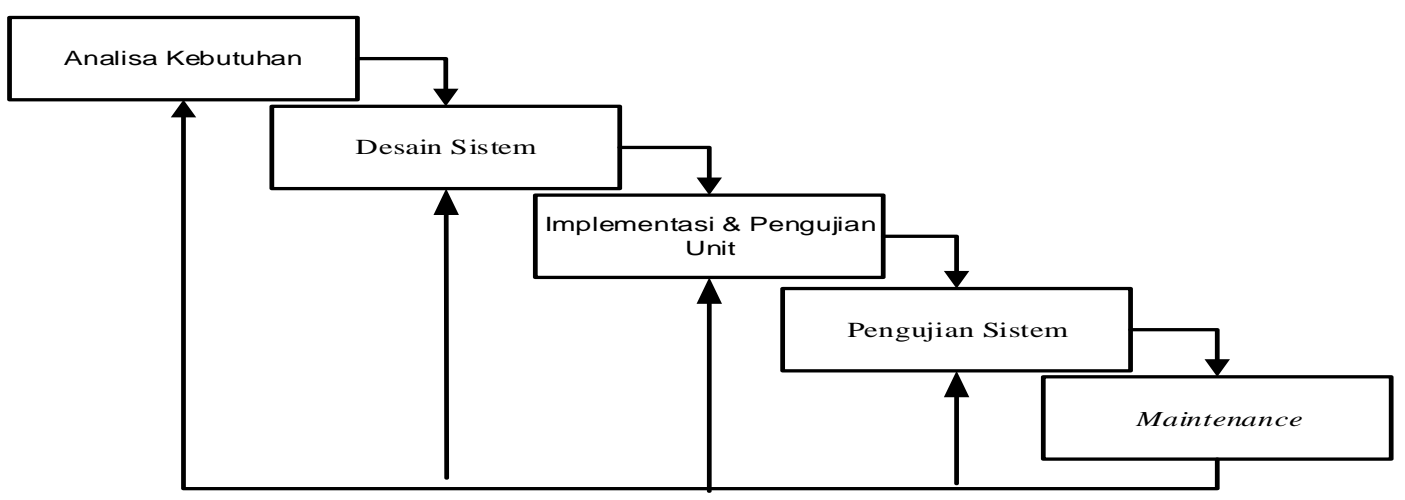

Gambar 6. Model Waterfall

Penjelasan dari metode pengembangan sistem yang terdapat pada Gambar 6 adalah sebagai berikut:

1) Analisis Kebutuhan

Pada tahap ini dilakukan identifikasi kebutuhan dari sistem yang akan dirancang seperti input dan ouput yang dibutuhkan, metode penyusutan yang diperlukan, laporan yang diperlukan dan sebagainya.

2) Desain Sistem

Pada tahap ini dilakukan perancangan data, antar muka (interface) dan model sistem dengan menggunakan Use-Case Diagram. Sedangkan untuk merancang prosedur dari sistem menggunakan Activity Diagram.

3) Implementasi dan Pengujian Unit

Pada tahap ini sistem yang telah dirancang, diimplementasikan dengan menggunakan program bantu yaitu PHP dan MySQL. Pengimplementasian dilakukan sesuai dengan rancangan sistem yang telah dibuat.

4) Pengujian Sistem

Di tahap ini, dilakukan proses pengujian atau testing terhadap rancangan sistem informasi yang dibangun untuk memastikan apakah semua fungsi sistem berjalan dengan baik dan mencari apakah masih ada kesalahan yang terjadi pada sistem sehingga dapat dilakukan perbaikan terhadap sistem yang mengalami kesalahan. Testing atau pengujian ini bertujuan untuk menjamin kualitas perangkat lunak atau software.

5) Maintenance/Perawatan

Tahap ini merupakan tahap terakhir dalam model waterfall. Software yang sudah jadi dijalankan dan telah digunakan oleh user serta dilakukan perawatan/Maintenance. Perawatan termasuk dalam memperbaiki kesalahan yang tidak ditemukan pada langkah sebelumnya.

\section{b. Analisa dan Perancangan Sistem}

Analisis Sistem Informasi Perolehan Dan Penyusutan Aktiva Tetap Yang Sedang Berjalan di PT. Hasil Damai Textile,Dari hasil analisa, terdapat beberapa kendala pada proses perhitungan penyusutan aktiva tetap yang masih manual dan belum efektif serta sulit mengidentifikasi aktiva tetap yang akan habis masa penyusutannya dan saat pembuatan rekap penyusutan aktiva selama setahun perusahaan harus melakukan penggabungan beberapa file menjadi satu sehingga tidak mudah bagi perusahaan untuk mengambil keputusan dalam menentukan pembelian aktiva tetap yang baru. Metodologi Penelitian Flow Map Proses Para Pegawai Pemakai Sistem Informasi dengan Program Sql. Langkah-langkah penelitian disajikan pada Gambar 7. 


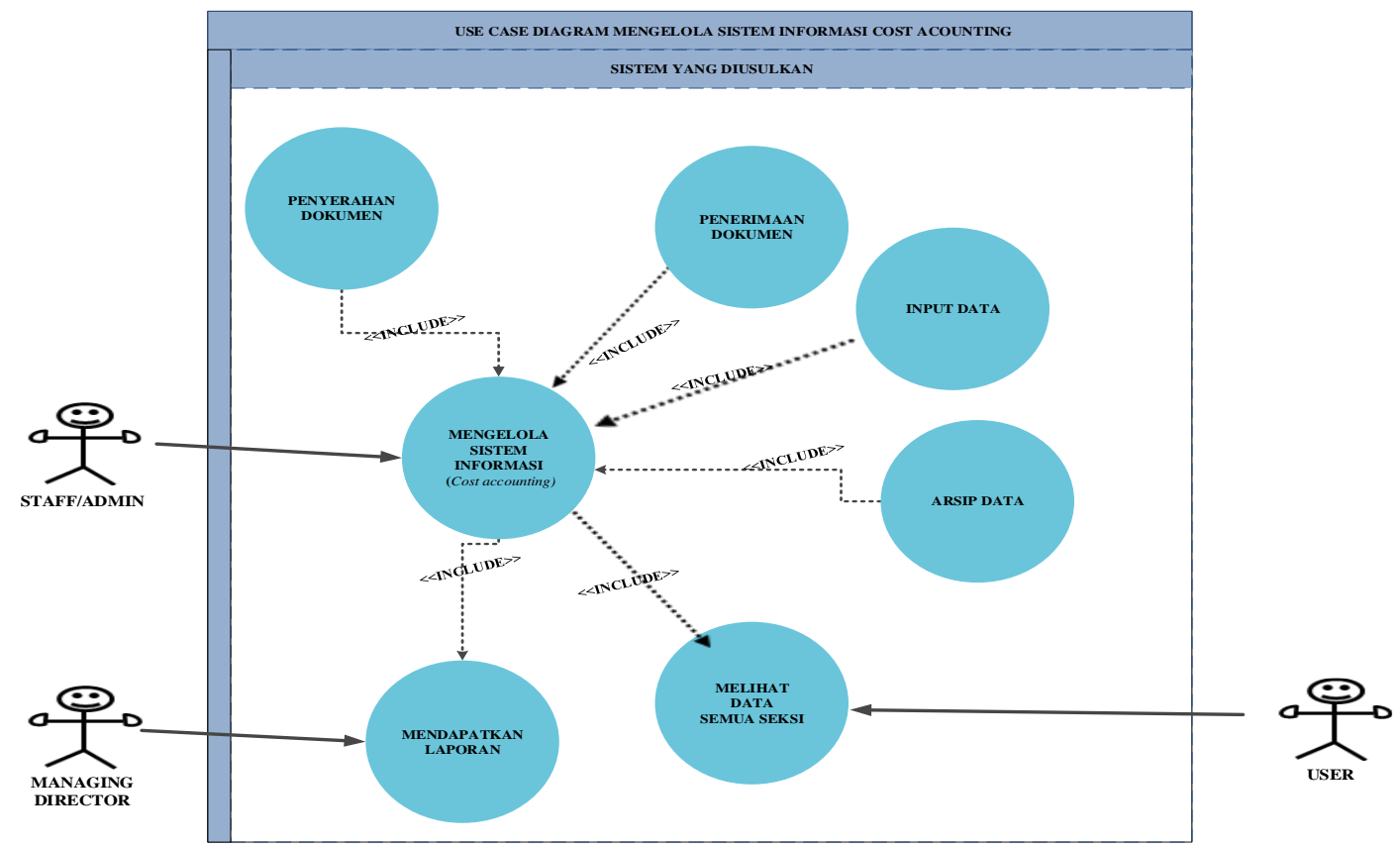

Gambar 7. Class Diagram Flowmap Yang Diusulkan

Uraian prosedur dari flowmap Gambar 7 adalah :

a. Purchasing menyerahkan dokumen pembelian aktiva tetap ke bagian Account payable (AP).

b. Account payable menerima dokumen pembelian dari purchasing kemudian menyimpan dokumen asli dan membuat copy dokumen pembelian tersebut untuk diberikan ke bagian Cost accounting.

c. Cost accounting menerima copy dokumen pembelian aktiva tetap kemudian melakukan input data akun, data barang, data perolehan dan data pembayaran

d. Cost accounting mengarsip copy dokumen pembelian aktiva tetap.

e. Cost accounting mencetak jurnal umum dan rekap penyusutan aktiva tetap untuk dilaporkan kepada Managing director.

Spesifikasi basis data merupakan definisi aribut atau data yang terkandung dalam setiap entitas pada basis data. Adapun struktur tabel yang diusulkan adalah sebagai berikut 


\section{HASIL DAN PEMBAHASAN}

\subsection{Analisis Sistem}

Dengan menganalisa sistem maka di hasilkan program yang berbasis Managemen Pemograman yang berbasis Sistem Query Language. Untuk masuk ke menu User Account dengan mengetik http://192.168.10.10/erp pada Mozilla Firefox. User account program sql disajikan pada Gambar 8.

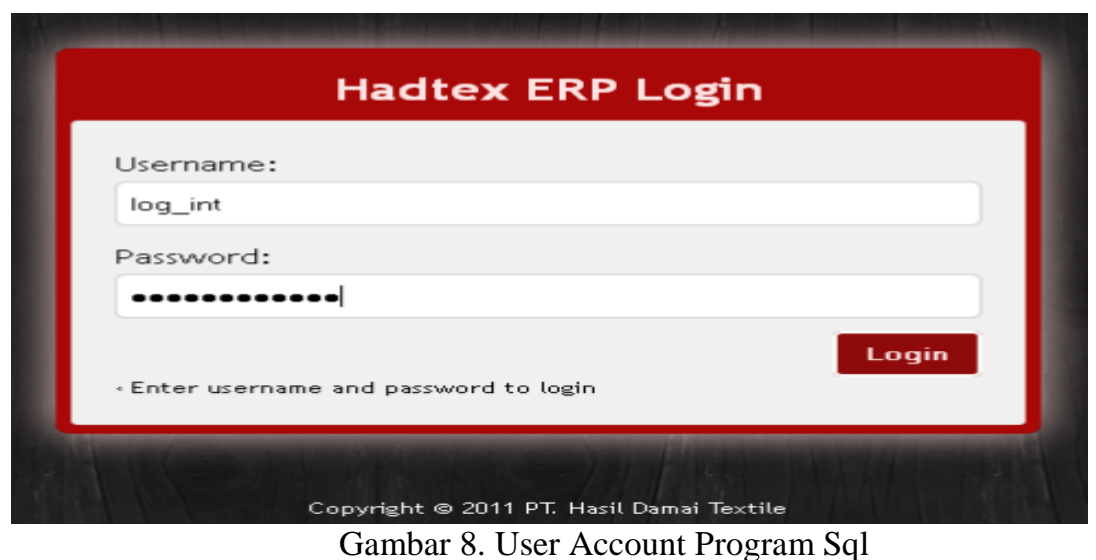

Untuk pemakaian program ERP cara inputkan Nama User (diisi nama lengkap) dan password (diisi dengan angka atau huruf) pada menu utama. Menu utama disajikan pada Gambar 9 dan tabel 1.

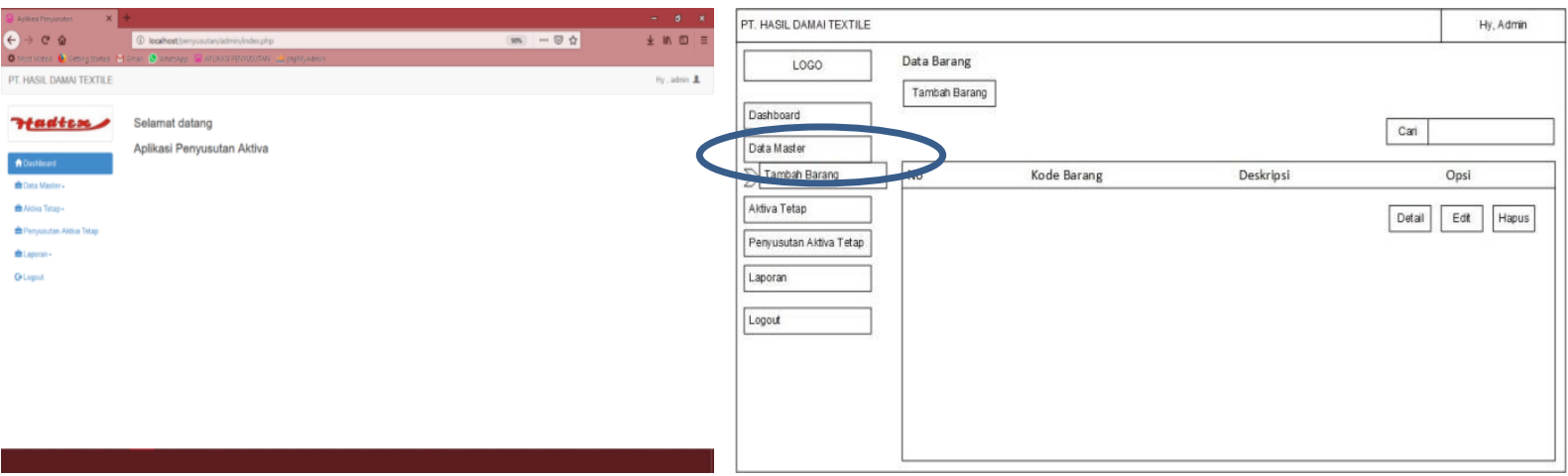

Gambar 9. Menu Utama

Tabel 1. Menu Utama

\begin{tabular}{|l|l|c|l|}
\hline \multicolumn{1}{|c|}{ Kolom } & \multicolumn{1}{|c|}{ Deskripsi } & Inputan & \multicolumn{1}{c|}{ Keterangan } \\
\hline Dashboard & & & \\
\hline Data Master & Checking data & H100 & Di isi dengan text dan angka \\
+ Tambah Barang & Input data barang & H100 & Di isi dengan text dan angka \\
Aktiva tetap & Checking barang & H100 & Di isi dengan text dan angka \\
Penyusutan Aktiva Tetap & Checking barang & H100 & Di isi dengan text dan angka \\
Laporan & Laporan & & \\
\hline
\end{tabular}

\subsection{Memulai Menu Utama}

Menampilkan form login dengan cara mengklik pada menu utama sehingga menampilkan halaman menu utama untuk memulai meng input. Master barang disajikan pada Gambar 10 dan tabel 2. 


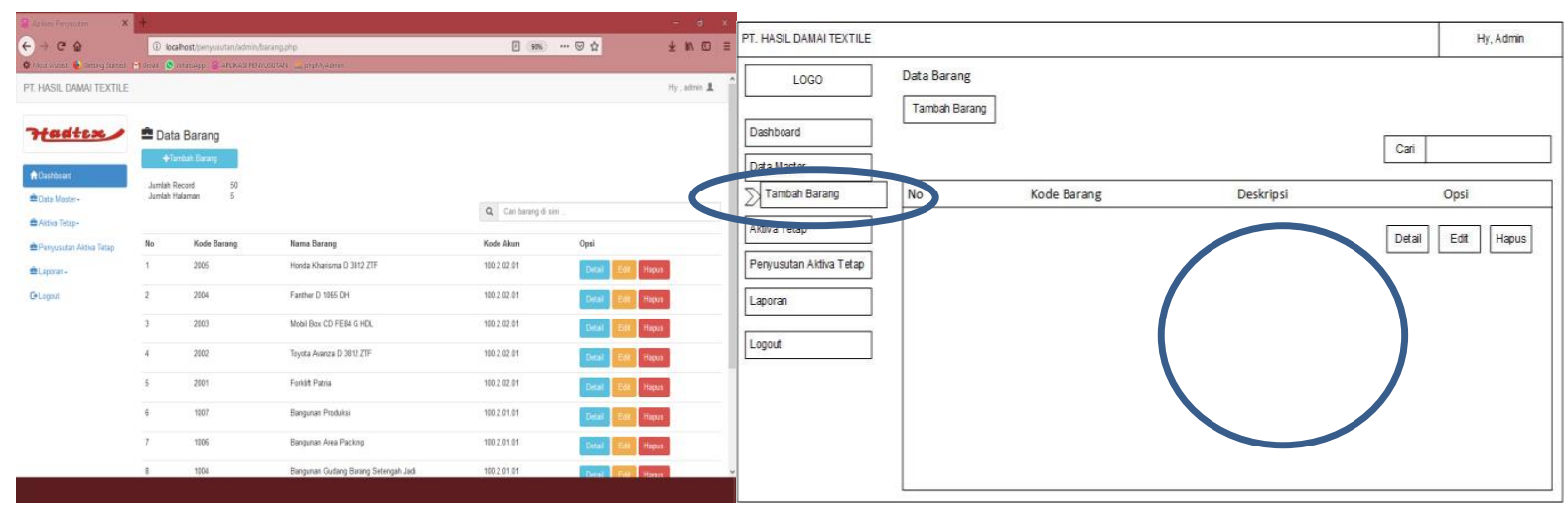

Gambar 10. Master barang

Tabel 2. Master Barang

\begin{tabular}{|l|l|l|l|}
\hline \multicolumn{1}{|c|}{ Kolom } & \multicolumn{1}{|c|}{ Deskripsi } & Inputan & \multicolumn{1}{c|}{ Keterangan } \\
\hline Dashboard & & & \\
\hline Data Master & Melihat semua datang barang & H100 & Di isi dengan text dan angka \\
\hline+ Tambah Barang & Input barang & H100 & Di isi dengan text dan angka \\
\hline Aktiva tetap & Data barang aktiva & H100 & Di isi dengan text dan angka \\
\hline Penyusutan Aktiva Tetap & Data barang yang susut & H100 & Di isi dengan text dan angka \\
\hline Laporan & & & \\
\hline
\end{tabular}

\subsection{Memulai Input Master Tambah Barang}

Dengan memulai input tambah barang adalah cara untuk menambah suatu barang yang akan dimasukan datanya ke dalan suatu program dengan meng klik tambah barang. Rancangan tambah perolehan aktiva tetap disajikan pada Gambar 11 dan tabel 3.

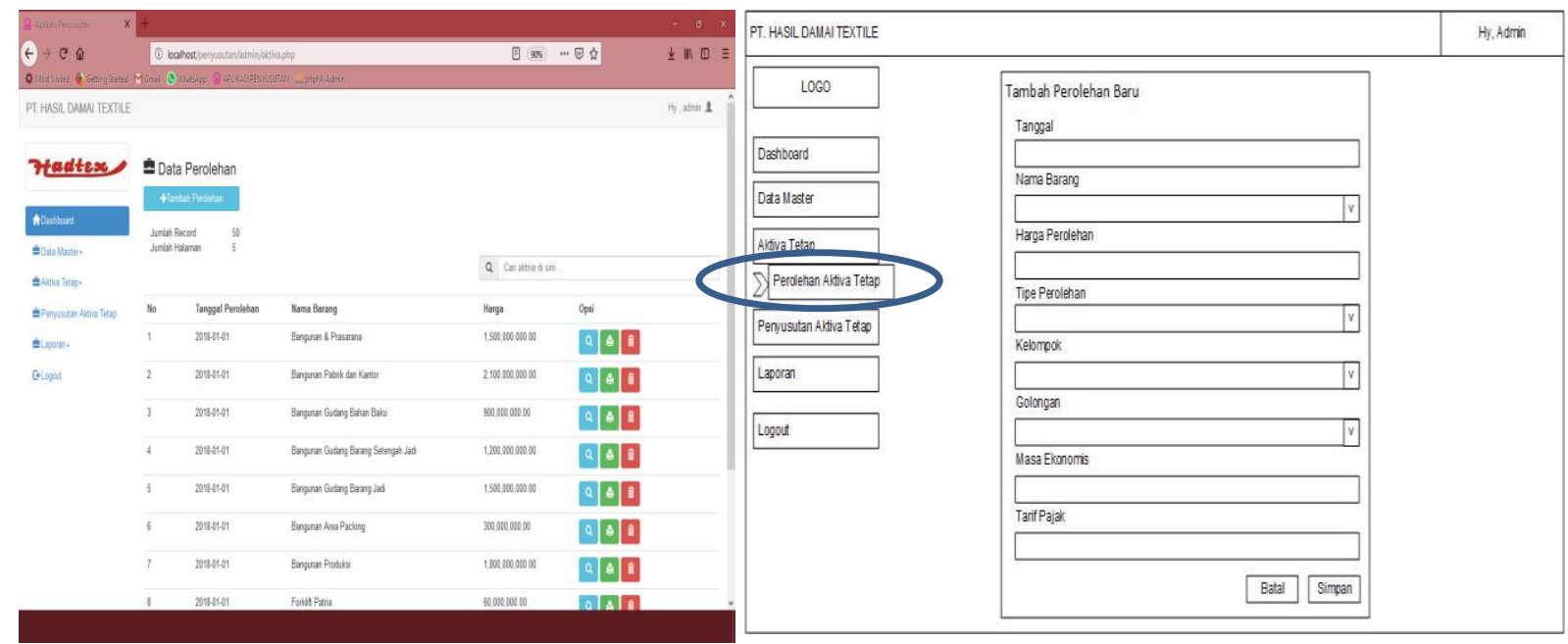

Gambar 11. Rancangan Tambah Perolehan Aktiva Tetap 
Tabel 3. Rancangan Tambah Perolehan Aktiva Tetap

\begin{tabular}{|l|l|l|l|}
\hline \multicolumn{1}{|c|}{ Kolom } & \multicolumn{1}{|c|}{ Deskripsi } & Inputan & \multicolumn{1}{c|}{ Keterangan } \\
\hline Dashboard & & & \\
\hline Data Master & Melihat semua datang barang & H100 & Di isi dengan text dan angka \\
Aktiva tetap & Data barang aktiva & H100 & Di isi dengan text dan angka \\
+ Penyusutan Aktiva Tetap & Data barang yang susut & H100 & Di isi dengan text dan angka \\
Perolehan Aktiva Teta & Input barang & H100 & Di isi dengan text dan angka \\
Laporan & & & \\
\hline
\end{tabular}

\subsection{Rancangan Tambah Perolehan Aktiva Tetap}

Teknis memulai input Tambah Perolehan Aktiva Tetap menampilkan form menu tambah data perolehan aktiva tetap dan menyimpannya dalam tabel perolehan. Rancangan tambah pembayaran hutang disajikan pada Gambar 12 dan tabel 4.

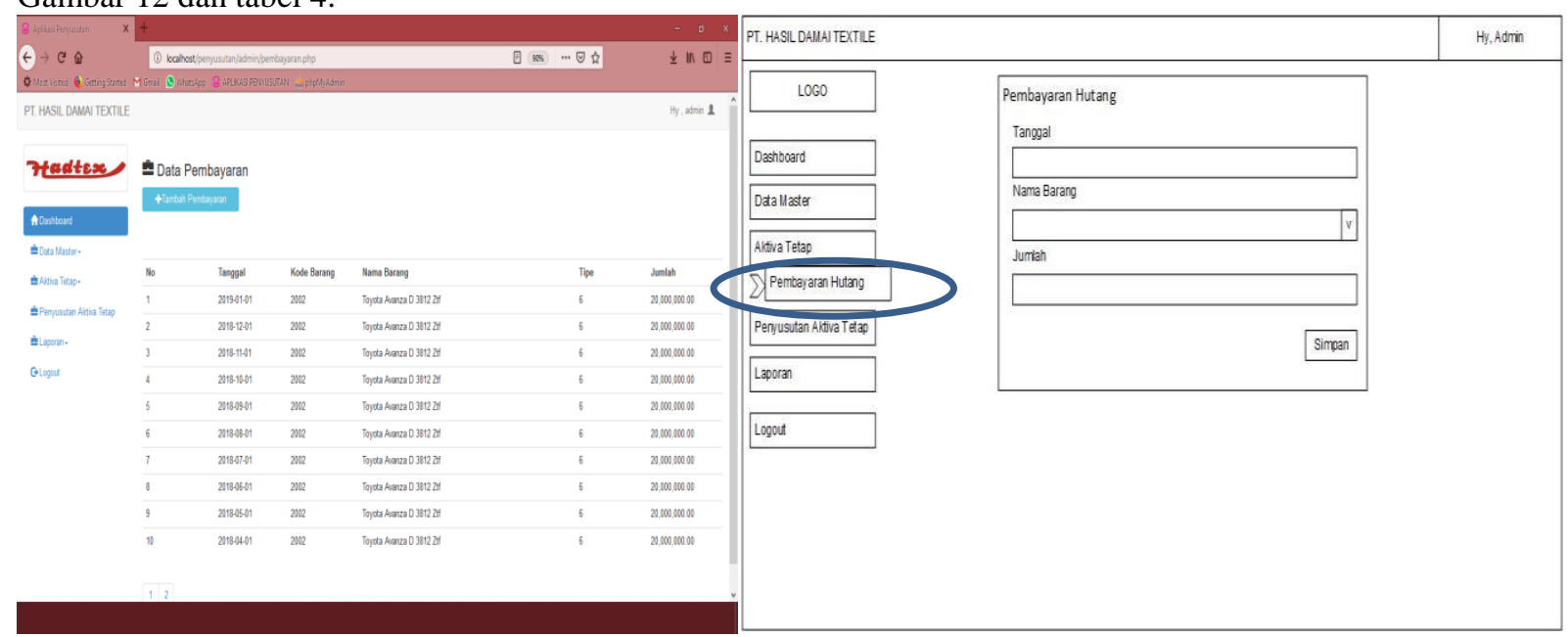

Gambar 12. Rancangan Tambah Pembayaran Hutang

Tabel 4. Rancangan Tambah Pembayaran Hutang

\begin{tabular}{|l|l|l|l|}
\hline \multicolumn{1}{|c|}{ Kolom } & \multicolumn{1}{|c|}{ Deskripsi } & Inputan & \multicolumn{1}{c|}{ Keterangan } \\
\hline Dashboard & & & \\
\hline Data Master & Melihat semua datang barang & H100 & Di isi dengan text dan angka \\
Aktiva tetap & Data barang aktiva & H100 & Di isi dengan text dan angka \\
+ Pembayaran Hutang & Data barang yang dibayar & H100 & Di isi dengan angka \\
Perolehan Aktiva Teta & Input barang & H100 & Di isi dengan text dan angka \\
Laporan & & & \\
\hline
\end{tabular}

\subsection{Rancangan Tambah Pembayaran Hutang}

Menampilkan form mеnu tambah data pembayaran hutang klik tambah pembayaran hutang ata pembayaran hutang berhasil disimpan. Rancangan perolehan aktiva tetap disajikan pada Gambar 13 dan tabel 5. 

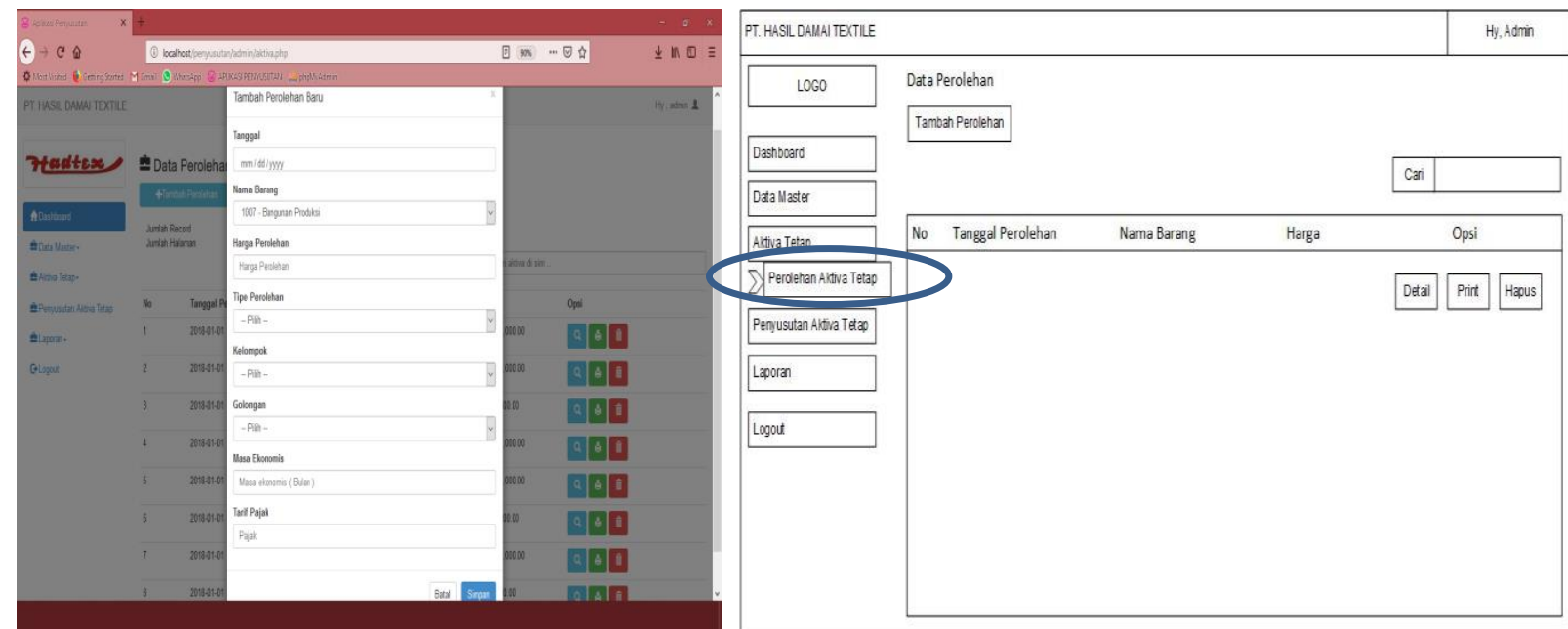

Gambar 13. Rancangan Perolehan Aktiva Tetap

Tabel 5. Rancangan Tambah Pembayaran Hutang

\begin{tabular}{|l|l|l|l|}
\hline \multicolumn{1}{|c|}{ Kolom } & \multicolumn{1}{|c|}{ Deskripsi } & Inputan & \multicolumn{1}{c|}{ Keterangan } \\
\hline Dashboard & & & \\
\hline Data Master & Melihat semua datang barang & H100 & Di isi dengan text dan angka \\
Aktiva tetap & Data barang aktiva & H100 & Di isi dengan text dan angka \\
+ Perolehan Aktiva Tetap & Pembayaran barang & H100 & Di isi angka \\
Penyusutan Aktiva Tetap & Input barang & H100 & Di isi dengan text dan angka \\
Laporan & & & \\
\hline
\end{tabular}

\subsection{Rancangan Perolehan Aktiva Tetap}

Detail data penyusutan aktiva tetap enampilkan halaman menu detail data penyusutan. Pembayaran hutang disajikan pada Gambar 14 dan tabel 6.

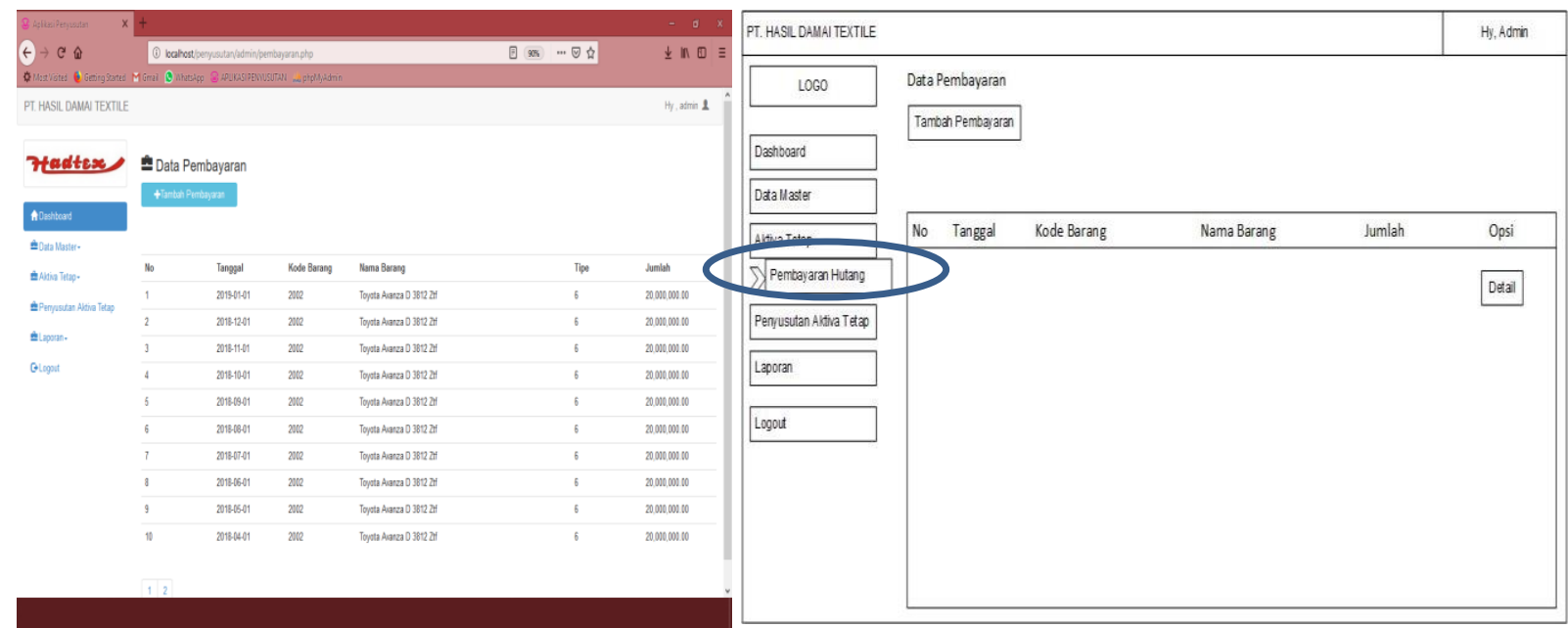

Gambar 14. Pembayaran Hutang 
Tabel 6. Pembayaran Hutang

\begin{tabular}{|c|c|c|c|}
\hline Kolom & Deskripsi & Inputan & Keterangan \\
\hline \multicolumn{4}{|l|}{ Dashboard } \\
\hline Data Master & Melihat semua datang barang & H100 & Di isi dengan text dan angka \\
\hline Aktiva tetap & Data barang aktiva & & Di isi dengan text dan angka \\
\hline + Pembayaran Hutang & Data barang yang dibayar & H100 & Di isi dengan angka \\
\hline Penyusutan Aktiva Tetap & Input barang & & Di isi dengan text dan angka \\
\hline Laporan & & & \\
\hline
\end{tabular}

\subsection{Pembayaran Hutang}

Detail data pembayaran hutang Menampilkan halaman menu detail data pembayaran. Laporan buku besar disajikan pada Gambar 15 dan tabel 7.

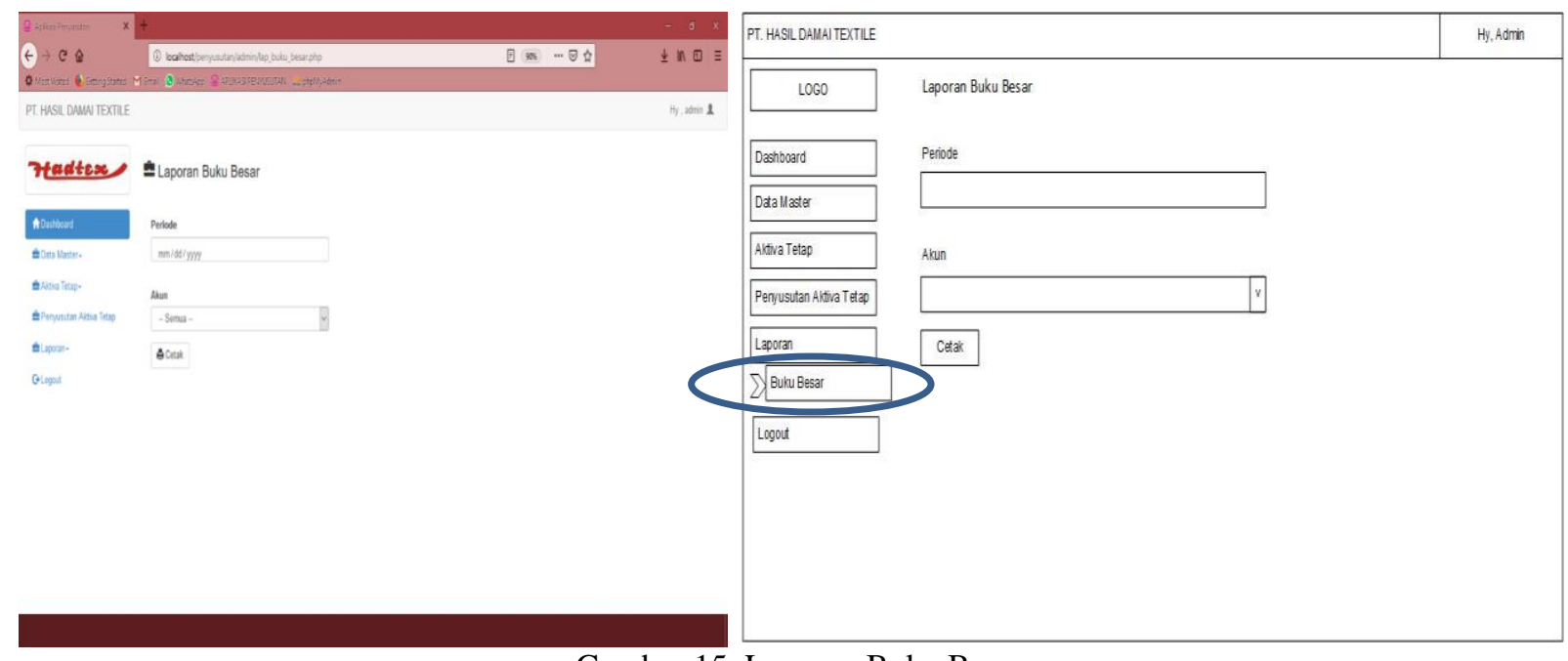

Gambar 15. Laporan Buku Besar

Tabel 7. Buku Besar

\begin{tabular}{|l|l|l|l|}
\hline \multicolumn{1}{|c|}{ Kolom } & \multicolumn{1}{|c|}{ Deskripsi } & \multicolumn{1}{c|}{ Inputan } & \multicolumn{1}{c|}{ Keterangan } \\
\hline Dashboard & \multicolumn{1}{|c|}{$\begin{array}{l}\text { Melihat semua datang barang } \\
\text { Data Master }\end{array}$} & H100 & Di isi dengan text dan angka \\
Aktiva tetap & H100 & Di isi dengan text dan angka \\
Penyusutan Aktiva Tetap & Input barang & H100 & Di isi dengan text dan angka \\
Laporan & Hasil laporan data barang & H100 & \\
Buku Besar & &
\end{tabular}




\subsection{Laporan Buku Besar}

Buat laporan buku besa Cetak laporan buku besar dalam bentuk pdf Dokumen laporan buku besar dalam bentuk pdf berhasil dicetak. Laporan aktiva tetap disajikan pada Gambar 16 dan tabel 8.

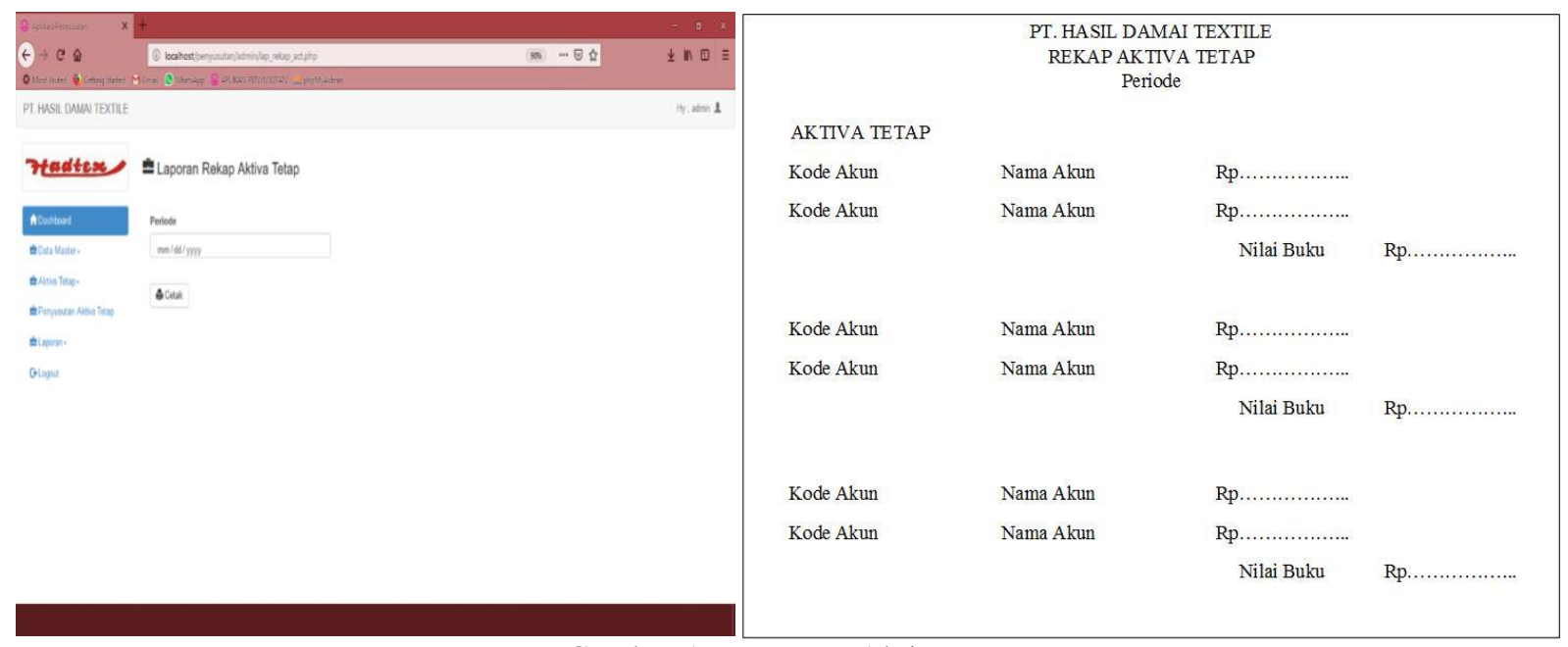

Gambar 16. Laporan Aktiva Tetap

Tabel 8. Laporan Aktiva Tetap

\begin{tabular}{|l|l|l|l|}
\hline \multicolumn{1}{|c|}{ Kolom } & \multicolumn{1}{|c|}{ Deskripsi } & Inputan & \multicolumn{1}{c|}{ Keterangan } \\
\hline Dashboard & & & \\
\hline Data Master & Melihat semua datang barang & H100 & Di isi dengan text dan angka \\
Aktiva tetap & Data barang aktiva & H100 & Di isi dengan text dan angka \\
Penyusutan Aktiva Tetap & Input barang & H100 & Di isi dengan text dan angka \\
Laporan & & & \\
Log Out & & & \\
\hline
\end{tabular}

\subsection{Laporan Aktiva Tetap}

Penerapan sistem informasi perolehan dan peyusutan dengan $p h p$ dan Mysql di PT. Hasil Damai Textile. Teknik pengujian sistem yang dipakai pada pengujian kali ini yaitu dengan menggunakan teknik pengujian black-box yang berfokus pada domain informasi dan perangkat lunak. Pengujian dilakukan dengan mencoba semua kemungkinan yang mengakibatkan error dan pengujian dilakukan berulang - ulang secara sistematis. Jika dalam program ditemukan kondisi yang tidak sesuai maka dilakukan penelusuran dan perbaikan hingga memenuhi persyaratan. Pengujian yang telah dilakukan selama membuat sistem informasi penjualan dengan $p h p$ dan mysql di PT. Hasil Damai Textile, antara lain:

a. Pengujian unit yaitu pengujian yang difokuskan pada suatu unit dari program secara sendiri

b. Pengujian penerimaaan yaitu pengujian yang meyakinkan bahwa sistem telah sesuai dengan kebutuhan.

\section{KESIMPULAN}

Berdasarkan hasil penelitian dan identifikasi masalah serta pembahasan sistem yang dianalisis, maka dapat diambil beberapa kesimpulan sebagai berikut:

a. Sistem pengolahan penyusutan aktiva tetap di PT. Hasil Damai Textile adalah masih menggunakan Microsoft excel cukup mengalami kesulitan. Tetapi setalah menggunakan aplikasi komputer berupa Sistem Informasi Web maka perolehan dan penyusutan aktiva tetap yang berguna dalam memudahkan proses pengolahan dan pelaporan data tersebut menjadi lebih efektif dan efisien. 
b. Metode pengembangan perangkat lunak dengan pemanfaatan Management Sistem Informasi program Sql dapat membantu dalam pembuatan software yang memiliki kualitas baik dikarenakan dengan adanya proses pengulangan dan bisa di acces.

\section{REFERENSI}

1. Al Fatta, H. (2009). Analisis dan Perancangan Sistem Informasi. Yogyakarta: Andi

2. Casavera. (2009). Perpajakan. Yogyakarta: Graha Ilmu

3. Fathansyah. (2012). Basis Data. Bandung: Informatika Bandung

4. Firdaus. (2008). Manajemen Agribisnis. Jakarta: Bumi Aksara

5. Juan. (2012). Panduan Praktis Standar Akuntansi Keuangan. Jakarta: Salemba Empat

6. Kadir, A. (2013). Pengenalan Sistem Informasi Edisi Revisi. Yogyakarta: Andi

7. Krismiaji. (2015). Sistem Informasi Akuntansi. Yogyakarta: Unit Penerbit

8. Kristanto, A. (2008). Perancangan Sistem Informasi dan Aplikasinya. Yogyakarta: Gava Media.

9. Nazir. M. (2013), Metode Penelitian. Bogor: Ghalia Indonesia

10. Rahardjo. (2007). Keuangan dan Akuntansi untuk Manajer Non Keuangan. Yogyakarta: Graha Ilmu

11. Raharjo, B. (2011). Belajar Otodidak Membuat Database Menggunakan Mysql. Bandung: Informatika Bandung 